\title{
THE EFFECT OF DIFFERENT IRRIGATION APPLICATIONS ON THE BLOSSOM-END ROT IN TREATED WASTEWATER- IRRIGATED TOMATOES (LYCOPERSICON ESCULENTUM)
}

\author{
DOĞAN DEMIR, A. ${ }^{{ }^{*}}-$ ŞAHIN, U. $^{2}-$ DEMIR, Y. $^{3}$ \\ ${ }^{I}$ Biosystem Engineering, Bingol University, Bingol, Turkey \\ ${ }^{2}$ Department of Agricultural Structures and Irrigation, Ataturk University, Erzurum, Turkey \\ ${ }^{3}$ Department of Soil Science and Plant Nutrition, Bingol University, Bingol, Turkey \\ *Corresponding author \\ e-mail: ademir@bingol.edu.tr; phone: +90-506-863-6806
}

(Received $14^{\text {th }}$ Nov 2018; accepted $16^{\text {th }}$ Jan 2019)

\begin{abstract}
The study investigates the effect of water deficit conditions on blossom-end rot (BER) in tomato. Drip irrigation was used in irrigation. Therefore, experiment was conducted as a randomized complete block design (three replicates), in a $2 \times 5$ factorial arrangement, corresponding to two different water resources [treated wastewater (TWW) and freshwater (FW)] and five different irrigation practices. The irrigation strategies comprised full irrigation (100\%), deficit irrigation, which involves the use of $75 \%$ and $50 \%$ of the water used in full irrigation, and partial root drying (PRD). According to the study results, in the full irrigation applications, blossom-end rot according to the fruit number values were $10.85 \%$ in fresh water irrigation while it was the lowest with $8.57 \%$ for treated wastewater. Also, in full irrigation applications, blossom-end rot values according to fruit weight were found to be lower compared to those in other applications. It was determined that there was a negative relation between blossom-end rot and $\mathrm{Ca}$ value. The lowest blossom-end rot incidence was observed in the full irrigation applications, while it was lower in the PRD applications than in the D applications. In the production of marketable tomato, the PRD applications can be more advantageous than the D applications under water shortage conditions.
\end{abstract}

Keywords: BER, wastewater, tomato, PRD, deficit irrigation

\section{Introduction}

The gap between water supply and demand is growing with the increasing global population and has reached life-threatening levels in certain regions of the world (Hussain et al., 2002). Moreover, although water of higher quality is suitable for household use, lower-quality waters are used in agricultural irrigation due to increasing demand for water in arid and semi-arid regions (Kızıloğlu et al., 2008). Thus, the need for the re-use of treated wastewaters is increasing. Today, according to recent estimates, 20 million hectares of agricultural land are irrigated with raw, processed or partiallydiluted wastewaters worldwide (Drechsel et al., 2010). In agricultural irrigation, water saving-oriented applications are also used in addition to the use of wastewaters to protect surface and underground water resources. Deficit irrigation and partial root drying methods are examples of these applications. The studies have shown that deficit irrigation and partial root drying yielded positive results in the reduction of agricultural water use (Doğan Demir, 2016). Partial root drying and deficit irrigation are fundamentally similar to each other but in the partial root drying method, a portion of the root remains dry while the rest is wetted depending on alternating wetting (Stikic et al., 2003). 
Various plant species are irrigated using wastewater with partial root drying and deficit irrigation. High yields can be achieved with the irrigation of tomato plants with partial root drying and deficit irrigation either using clean water or wastewater and there are various studies investigating this subject (Al-Lahham et al., 2007; Li et al., 2007; Ekici, 2002; Alrajhi et al., 2015; Zegbe et al., 2007), but certain diseases may develop and cause yield losses due to applications. In tomatoes, blossom-end rot is the most common issue with these applications. Blossom-end rot in tomato has been described as a physical disorder for more than a century (Selby, 1896; Spurr, 1959; Saure, 2001; Ho and White, 2005; Taylor and Locascio, 2004). Although low calcium content has generally been reported to be the cause of blossom-end rot in tomato, various factors including acidic growing media, high $\mathrm{N}$ content, high soil salinity, low soil moisture and soil dryness have also been reported to affect the development of blossom-end rot (Selby, 1896; Shaykewich et al., 1971; Pill and Lambeth, 1980; Winsor and Adams, 1987; Ikeda and Osawa, 1988; Ho et al., 1999; Saure, 2001; Taylor and Locascio, 2004; Zhai et al., 2015).

There is limited information about the effects of water deficit and water stress on plant nutrition. In general, the nitrogen concentration in plant tissues increases with water stress. On the other hand, the phosphorus concentration in plants has been reported to decrease with decreasing water (Reichman and Grunes, 1966; Greenway et al., 1966; Thorup, 1969). The relationship between moisture deficit in soils and plant nutrition affects blossom-end rot development in tomatoes (Shaykewich et al., 1971; Bost, 2010). Tan and Dhanvantari (1985) reported that blossom-end rot development in tomatoes was reduced with irrigation. The water stress in plants increases under water deficit conditions, which results in blossom-end rot (Shaykewich et al., 1971; Ward, 1973).

Although partial root drying is a variation of deficit irrigation, deficit irrigation has been reported to aggravate blossom-end rot development in tomatoes (Adams and Ho, 1992; Obreza et al., 1996; Taylor et al., 2004; Sun, 2013). The irrigation method also affects the development of blossom-end rot (Carrijo et al., 1983).

For the detection of blossom-end rot (BER), total fruit number and rotten fruit number were determined. The number of the fruits with a rotten blossom-end were divided by the total fruit number and the blossom-end rot was given in percentages in the calculations. Furthermore, blossom-end rot value was also determined in percentages with respect to fruit weight. For this purpose, the weights of the fruits with a rotten blossom-end were measured and divided by the total weight of the fruits (Koral, 2006).

Studies have reported that the ratio of $\mathrm{K} / \mathrm{Ca}$ was a more deterministic indicator of blossom-end rot in tomato than $\mathrm{Ca}$ content and the ratio between $\mathrm{K}$ and $\mathrm{Ca}$ and $\mathrm{Ca}$ content were related with each other (Gerard and Hipp, 1968; DeKock et al., 1982; Nukaya et al., 1994). Thus, this study also investigates the relationships between the Ca, $\mathrm{K} / \mathrm{Ca}$ and $\mathrm{K}+\mathrm{Mg} / \mathrm{Ca}$ contents of the leaves and upper $30 \mathrm{~cm}$ of the soil and blossom-end rot. Moreover, the study examines the relationship between blossom-end rot and nitrogen and salinity values, which are thought to affect blossom-end rot.

The study investigates the effects of partial root drying (PRD) and deficit irrigation (D) on blossom-end rot (BER) in the tomato plants irrigated with treated wastewater. 


$$
\text { - } 2137 \text { - }
$$

\section{Materials and methods}

The mean elevation of the study area (Fig. 1) from sea level was $1030 \mathrm{~m}$ and the study area is located at latitude $38^{\circ} 53^{\prime} 01.91^{\prime \prime}-38^{\circ} 53^{\prime} 01.52^{\prime \prime} \mathrm{N}$ and longitude $40^{\circ} 32$ '57.82” - 40³2'56.73” E.

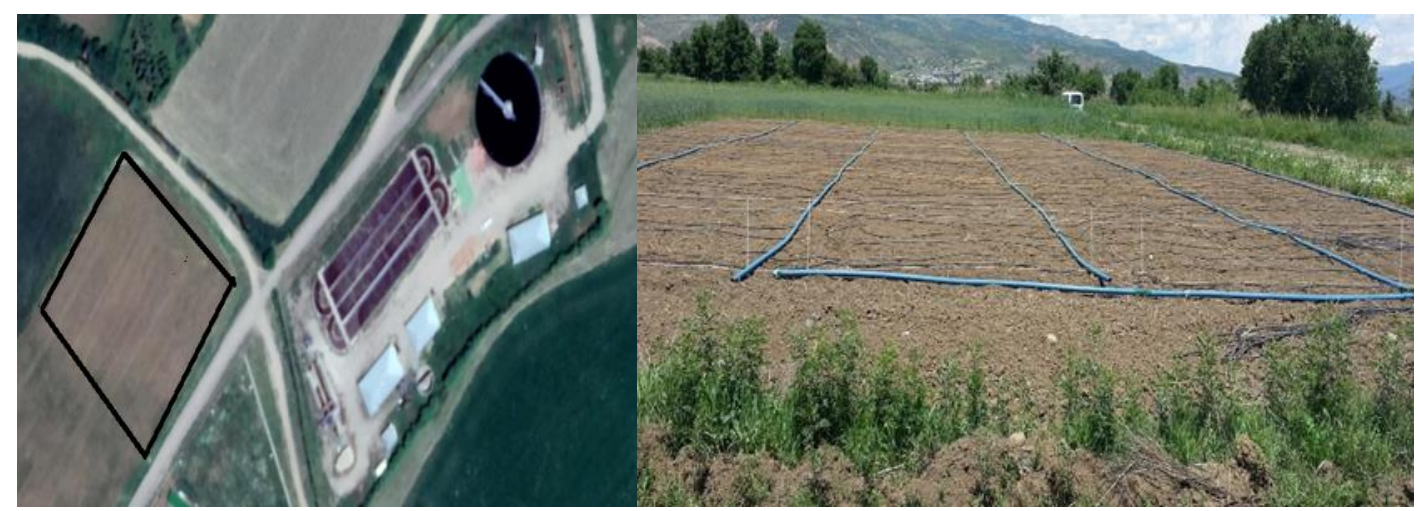

Figure 1. Study area

Table 1 shows the long-term average climatic data and climatic data for the study year in Bingöl, Turkey, as obtained from the meteorology station.

Table 1. The long term average climatic data and climatic data for the study year in Bingöl, Turkey

\begin{tabular}{c|c|c|c|c|c|c|c}
\hline Year & Month & $\begin{array}{c}\text { Temperature } \\
\left({ }^{\circ} \mathbf{C}\right)\end{array}$ & $\begin{array}{c}\text { Relative } \\
\text { humidity } \\
(\mathbf{\%})\end{array}$ & $\begin{array}{c}\text { Wind } \\
\text { speed } \\
\left(\mathbf{m} / \mathbf{s}^{-1}\right)\end{array}$ & $\begin{array}{c}\text { Daily } \\
\text { sunshine } \\
(\mathbf{h})\end{array}$ & $\begin{array}{c}\text { Evaporation } \\
(\mathbf{m m})\end{array}$ & $\begin{array}{c}\text { Precipitation } \\
(\mathbf{m m})\end{array}$ \\
\hline \multirow{3}{*}{$\begin{array}{c}\text { Long } \\
\text { term }\end{array}$} & May & 16.3 & 55.8 & 1.9 & 7.31 & 116.5 & 75.1 \\
$(1960-$ & June & 22.1 & 43.5 & 2.1 & 9.40 & 179.1 & 20.6 \\
$2013)$ & July & 26.7 & 35.9 & 2.2 & 9.54 & 231.2 & 5.7 \\
& August & 26.4 & 35.1 & 2.1 & 9.24 & 221.7 & 3.3 \\
& September & 21.1 & 41.0 & 1.9 & 8.31 & 158.2 & 10.4 \\
\hline \multirow{2}{*}{2013} & May & 18.7 & 47.8 & 0.87 & 7.20 & 12 & 7.0 \\
& June & 22.8 & 33.3 & 1.04 & 8.84 & 181 & 6.2 \\
& July & 27.2 & 26.4 & 1.28 & 9.39 & 278 & - \\
& August & 26.4 & 26.2 & 1.08 & 9.19 & 255 & - \\
& September & 20.3 & 34.5 & 0.83 & 7.95 & 111 & 10.9 \\
\hline
\end{tabular}

\&Includes the vegetation period in May and September of 2013

*The precipitation and evaporation values for 2013 were measured using a rain gauge and an A-class evaporation pan installed in the study area.

A profile was dug to determine the soil properties in the study area and disturbed and undisturbed soil samples were collected from the depths of 0-30, 30-60 and 60-90 cm of the soil profile, followed by the analyses of the physical, chemical and hydraulic properties of the soil samples (Table 2). 
Table 2. Basal properties of experimental field soil prior to trial

\begin{tabular}{c|c|c|c}
\hline \multirow{2}{*}{ Parameter } & \multicolumn{3}{|c}{ Soil layer $(\mathbf{c m})$} \\
\cline { 2 - 4 } & $\mathbf{0 - 3 0}$ & $\mathbf{3 0 - 6 0}$ & $\mathbf{6 0 - 9 0}$ \\
\hline Texture & Clay & Clay & Clay \\
Bulk density $\left(\mathrm{mg} \mathrm{m}^{-3}\right)$ & 1.30 & 1.31 & 1.36 \\
Field capacity $(\%$ of weight $)$ & 28.5 & 30.3 & 30.8 \\
Wilting point $(\%$ of weight $)$ & 17.2 & 18.1 & 18.4 \\
$\mathrm{pH}$ & 8.01 & 7.94 & 7.92 \\
$\mathrm{EC}\left(\mathrm{dS} \mathrm{m}^{-}\right)$ & 0.528 & 0.509 & 0.450 \\
Organic matter $(\%)$ & 1.6 & 1.3 & 1.1 \\
$\mathrm{CaCO}(\%)$ & 4.60 & 3.40 & 2.10 \\
$\mathrm{Total} \mathrm{N}(\%)$ & 0.08 & 0.07 & 0.05 \\
$\mathrm{P}_{2} \mathrm{O}\left(\mathrm{kg} \mathrm{da}^{-}\right)$ & 8.30 & 5.7 & 1.5 \\
$\mathrm{~K}_{2} \mathrm{O}\left(\mathrm{kg} \mathrm{da}^{-}\right)$ & 71.3 & 66.2 & 58.8 \\
$\mathrm{Ca}\left(\mathrm{cmol} \mathrm{kg}^{-}\right)$ & 25.1 & 28.7 & 29.4 \\
$\mathrm{Mg}\left(\mathrm{cmol} \mathrm{kg}^{-}\right)$ & 5.60 & 4.63 & 4.84 \\
$\mathrm{Na}\left(\mathrm{cmol} \mathrm{kg}^{-}\right)$ & 0.50 & 0.40 & 0.40 \\
$\mathrm{~B}\left(\mathrm{mg} \mathrm{kg}^{-}\right)$ & 0.57 & 0.51 & 0.54 \\
$\mathrm{Fe}\left(\mathrm{mg} \mathrm{kg}^{-}\right)$ & 14.5 & 15.7 & 15.0 \\
$\mathrm{Zn}\left(\mathrm{mg} \mathrm{kg}^{-}\right)$ & 0.60 & 0.80 & 0.40 \\
$\mathrm{Cu}\left(\mathrm{mg} \mathrm{kg}^{-}\right)$ & 0.60 & 0.80 & 0.80 \\
$\mathrm{Mn}\left(\mathrm{mg} \mathrm{kg}^{-}\right)$ & 13.2 & 11.3 & 12.7 \\
$\mathrm{Cd}\left(\mathrm{mg} \mathrm{kg}^{-}\right)$ & 0.20 & 0.30 & 0.30 \\
$\mathrm{Ni}\left(\mathrm{mg} \mathrm{kg}^{-}\right)$ & 1.90 & 1.40 & 0.90 \\
$\mathrm{~Pb}\left(\mathrm{mg} \mathrm{kg}^{-}\right)$ & 0.09 & 0.09 & 0.05 \\
\hline
\end{tabular}

The Joker- $\mathrm{F}_{1}$ (Lycopersicon esculentum) variety was used in the study. In the trials, Joker F1 tomato variety was chosen due to the fact that it is a very strong variety that can cover the fruit, it is more resistant to diseases, it has can highly adapt to the region, it yields a hard fruit with a long shelf-life and it is suitable for temporary and long-term harvest. The seedlings were planted in the field on May 20. Prior to planting, plough cultivation was applied, large clods were crushed and field surface was smoothed to prepare the conditions for planting. The plants were planted in 5 rows with an inter-row spacing of $100 \mathrm{~cm}$ and intra-row spacing of $50 \mathrm{~cm}$. Weeding was carried out manually through hoeing three times until the first harvest. Nitrogenous, phosphorous and potassium fertilizers were used in fertilization. Prior to planting, compound Diammonium Phosphate (DAP) (20:20:0) was applied in the dose of $50 \mathrm{~kg}$ per decare. Equal fertilization to each plant was carried out until reaching a cover level of $30 \%$ and irrigation conditions were met; after planting, in each irrigation, the NPK 15:15:15 and potassium nitrate 13-0-46 fertilizers were applied in the amount of $10 \mathrm{~kg}$ (50 kg in total) using a drip irrigation system. To control the more cricket population, the Korban-4 insecticide was used after planting. The experiments were carried out using waters of two different qualities in the applications, i.e. freshwater (FW) and treated wastewater (TWW). The quality result of each parameter in the Table 3 shows the three sampling periods (June, July, and August). The clean water was obtained from the open irrigation channel at the entrance of the field and the wastewater was obtained from the exit of the wastewater treatment plant of Bingöl. Table 3 shows the properties of the irrigation waters. 
Table 3. The quality of the irrigation waters

\begin{tabular}{|c|c|c|c|c|c|c|}
\hline \multirow{2}{*}{ Parameter } & \multicolumn{2}{|c|}{ June } & \multicolumn{2}{|c|}{ July } & \multicolumn{2}{|c|}{ August } \\
\hline & TWW & FW & TWW & FW & TWW & FW \\
\hline $\mathrm{pH}-$ & 7.08 & 7.75 & 8.15 & 8.49 & 8.05 & 8.22 \\
\hline $\mathrm{EC}\left(\mathrm{dS} \mathrm{m}^{-}\right)$ & 0.480 & 0.172 & 0.529 & 0.159 & 0.533 & 0.158 \\
\hline TSS (mg l-) & 20.3 & 21.2 & 16.0 & 17.8 & 28.0 & 21.3 \\
\hline Total $\mathrm{N}\left(\mathrm{mg} \mathrm{l}^{-}\right)$ & 14.9 & - & 13.0 & - & 13.41 & - \\
\hline Total P (mg l-) & 1.95 & - & 2.00 & - & 1.86 & - \\
\hline $\mathrm{CO}_{3}\left(\mathrm{me} \mathrm{l}^{-}\right)$ & 0 & 0 & 0 & 0 & 0.10 & 0.03 \\
\hline $\mathrm{HCO}_{3}\left(\mathrm{me} \mathrm{l}^{-}\right)$ & 0.30 & 0.27 & 0.51 & 0.34 & 0.29 & 0.22 \\
\hline $\mathrm{SO}_{4}\left(\mathrm{me} \mathrm{l}^{-}\right)$ & 3.90 & 1.20 & 2.85 & 1.43 & 2.89 & 1.41 \\
\hline $\mathrm{Cl}\left(\mathrm{me} \mathrm{l}^{-}\right)$ & 0.50 & 0.65 & 1.30 & 0.45 & 1.92 & 0.23 \\
\hline $\mathrm{Ca}\left(\mathrm{me} \mathrm{l}^{-}\right)$ & 1.59 & 1.16 & 2.58 & 1.23 & 2.11 & 0.91 \\
\hline $\operatorname{Mg}\left(\mathrm{me} \mathrm{l}^{-}\right)$ & 0.99 & 0.77 & 1.09 & 0.83 & 1.88 & 0.74 \\
\hline $\mathrm{Na}\left(\mathrm{me} \mathrm{l}^{-}\right)$ & 2.02 & 0.16 & 0.54 & 0.13 & 0.95 & 0.23 \\
\hline $\mathrm{K}\left(\mathrm{me} \mathrm{l}^{-}\right)$ & 0.14 & 0.07 & 0.41 & 0.04 & 0.49 & 0.05 \\
\hline $\mathrm{B}\left(\mathrm{mg} \mathrm{l}^{-}\right)$ & 0.19 & 0.03 & 0.54 & 0.34 & 0.57 & 0.39 \\
\hline $\mathrm{Fe}\left(\mathrm{mg} \mathrm{l}^{-}\right)$ & 0.46 & 0.23 & 0.09 & 0.06 & 0.15 & 0.10 \\
\hline $\mathrm{Cu}\left(\mathrm{mg} \mathrm{l}^{-}\right)$ & 0.13 & 0.09 & 0.05 & 0.03 & 0.09 & 0.04 \\
\hline $\mathrm{Ni}\left(\mathrm{mg} \mathrm{l}^{-}\right)$ & 0.03 & 0.04 & 0.05 & 0.05 & 0.05 & 0.04 \\
\hline $\mathrm{Cd}\left(\mathrm{mg} \mathrm{l}^{-}\right)$ & 0.07 & 0.05 & 0.11 & 0.07 & 0 & 0 \\
\hline $\operatorname{Mn}\left(\mathrm{mg} \mathrm{l}^{-}\right)$ & 0.11 & 0.06 & 0.09 & 0.03 & 0.02 & 0.01 \\
\hline $\mathrm{Zn}\left(\mathrm{mg} \mathrm{l}^{-}\right)$ & 0.05 & 0.04 & 0.04 & 0.04 & 0.08 & 0.04 \\
\hline $\mathrm{Pb}\left(\mathrm{mg} \mathrm{l}^{-}\right)$ & 0.02 & 0.02 & 0.09 & 0.07 & 0.08 & 0.05 \\
\hline $\mathrm{Cr}\left(\mathrm{mg} \mathrm{l}^{-}\right)$ & 0.35 & 0.25 & 0.46 & 0.42 & 0.41 & 0.37 \\
\hline $\mathrm{Co}\left(\mathrm{mg} \mathrm{l}^{-}\right)$ & 0.19 & 0.17 & 0.20 & 0.16 & 0.19 & 0.17 \\
\hline $\mathrm{BOD}_{5}\left(\mathrm{mg} \mathrm{l}^{-}\right)$ & 24.0 & - & 25.0 & - & 36.0 & - \\
\hline $\mathrm{COD}\left(\mathrm{mg} \mathrm{l}^{-}\right)$ & 67.2 & - & 63.8 & - & 96.0 & - \\
\hline$\% \mathrm{Na}(\%)$ & 42.62 & 20.22 & 11.69 & 5.30 & 17.49 & 9.50 \\
\hline SAR - & 1.77 & 0.54 & 0.40 & 0.12 & 0.67 & 0.22 \\
\hline $\mathrm{RSC}\left(\mathrm{me} \mathrm{l}^{-}\right)$ & -2.28 & -1.87 & -3.16 & -1.94 & -3.60 & -1.89 \\
\hline
\end{tabular}

$T W W$ treated wastewater, $F W$ freshwater, $E C$ electrical conductivity, $T S S$ total suspended solids, $B O D_{5}$ 5-day biochemical oxygen demand, COD chemical oxygen demand, SAR sodium adsorption ratio, RSC residual sodium carbonate

Drip irrigation was used in irrigation. Therefore, experiment was conducted as a randomized complete block design (three replicates), in a $2 \times 5$ factorial arrangement, corresponding to two different water resources [treated wastewater (TWW) and freshwater $(\mathrm{FW})]$ and five different irrigation practices. The irrigation strategies comprised full irrigation (100\%), deficit irrigation, which involves the use of $75 \%$ and $50 \%$ of the water used in full irrigation, and partial root drying (PRD). In all applications, waters of two different qualities (clean water and wastewater) were used. In each parcel, 6 lateral pipes were installed in the middle of each plant row pair with a spacing of $100 \mathrm{~cm}$; the irrigation water was applied from all lateral pipes in full and deficit irrigation applications, while the irrigation water was alternately applied in the partial root drying method [from no. 1-3-5 lateral pipes in odd-number irrigations; from 


$$
-2140 \text { - }
$$

no. 2-4-6 lateral pipes in even-number irrigations]. The amount of irrigation water were equal in wastewater and clean water applications and adjusted in accordance with the control application in which $100 \%$ full irrigation was applied. The irrigations were commenced immediately after planting and finalized on September 29, when the growing season ended. Table 4 shows the total and monthly irrigation water amounts in different applications. A total of $640.2 \mathrm{~mm}$ irrigation water was used in the $100 \%$ full irrigation application to tomato plants. The lowest irrigation water amount was $338.3 \mathrm{~mm}$ and applied in the 50\% D and 50\% PRD applications (Table 4).

Table 4. The amounts of monthly and seasonal irrigation water applications to tomato plants in different irrigation applications ( $\mathrm{mm}$ )

\begin{tabular}{c|c|c|c|c|c|c}
\hline \multirow{2}{*}{ Application } & \multicolumn{7}{|c}{ Months } \\
\cline { 2 - 7 } & May & June & July & August & September & Total \\
\hline \% 100 & 10.6 & 37.0 & 219 & 207.6 & 166.1 & 640.2 \\
\% 75 D & 10.6 & 34.2 & 164.3 & 155.7 & 124.6 & 489.3 \\
\% 50 D & 10.6 & 31.4 & 109.5 & 103.8 & 83.1 & 338.3 \\
\% 75 PRD & 10.6 & 34.2 & 164.3 & 155.7 & 124.6 & 489.3 \\
\% 50 PRD & 10.6 & 31.4 & 109.5 & 103.8 & 83.1 & 338.3 \\
\hline
\end{tabular}

$\% 100$ full irrigation, $75 D$ and $50 D 75$ and 50\% deficit irrigation, $75 P R D$ and $50 P R D 75$ and $50 \%$ deficit irrigation with PRD

Irrigation quantities in the scheduled irrigation period were corrected using a coefficient of 0.50 for the 50D and 50 PRD treatments and using a coefficient of 0.75 for the 75D and 75PRD treatments (Table 4).

BER were calculated using the below equations (Eqs. 1-2; Koral, 2006):

$$
B E R=\frac{N f}{N t f} x 100
$$

where $B E R$ is the blossom-end rot $(\%), N f$ number of rotten fruits, $N t f$ total number of fruits.

$$
B E R=\frac{M f}{M t f} x 100
$$

where $B E R$ is the blossom-end rot (\%), $M f$ rotten fruits weight $(\mathrm{kg}), M t f$ total fruit weight $(\mathrm{kg})$.

The changes in soil moisture were measured before the irrigations and showed that moisture did not drop to the wilting point in any of the applications throughout the growing season and the available water was reduced about $40 \%$ in the full irrigation application. A growing period of minumum $30 \%$ was provided and water was given equal to each plant until irrigation issues started. In general, the soil moisture values in the 75\% PRD and 50\% PRD applications were the closest values to the wilting point according to the soil moisture values. The changes in soil moisture during the growing season were close to each other in all applications (Table 5.) 
Table 5. The changes in soil moisture in different irrigation applications in the study year (\%)

\begin{tabular}{|c|c|c|c|c|c|c|c|c|c|c|c|}
\hline $\mathbf{F}$ & $100 \%$ & $\begin{array}{c}\% 50 \\
\mathrm{D}\end{array}$ & $\begin{array}{l}\% 50 \\
\text { PRD } \\
\end{array}$ & $\begin{array}{c}\% 75 \\
\text { D } \\
\end{array}$ & \begin{tabular}{|l|}
$\% 75$ \\
PRD \\
\end{tabular} & & $100 \%$ & $\begin{array}{c}\% 50 \\
\mathrm{D}\end{array}$ & $\begin{array}{l}\% 50 \\
\text { PRD } \\
\end{array}$ & $\begin{array}{c}\% 75 \\
\text { D }\end{array}$ & \begin{tabular}{|l|l}
$\% 75$ \\
PRD \\
\end{tabular} \\
\hline n1 & 24.79 & 24.79 & .79 & 24.79 & 4.79 & & th & 24.79 & 24.79 & 24.79 & 24.79 \\
\hline Irri & 25.29 & 29 & .29 & 29 & 29 & & 25.29 & 29 & .29 & .29 & 29 \\
\hline Irrigation3 & 25.25 & .25 & .25 & .25 & 5.25 & Irrigation3 & 25.25 & 25.25 & 5.25 & 5.25 & .25 \\
\hline Irrigation4 & 23.89 & 89 & 39 & .89 & 3.89 & n4 & 23.89 & 23.89 & 23.89 & 23.89 & 23. \\
\hline Irrigation5 & 25.37 & .37 & .37 & .37 & 5.37 & Irrigation5 & 25.37 & 25.37 & 25.37 & 25.37 & JI \\
\hline Irrigation5 & 23.57 & 57 & 23.57 & 23.57 & 23.57 & tion5 & 23.57 & 57 & 23.57 & 23.57 & .57 \\
\hline Irrigation6 & 24.9 & 97 & .97 & 97 & 97 & & 24.97 & & 97 & 97 & 19.8 \\
\hline Irrigation 7 & 24.02 & .02 & 1.02 & 1.02 & 24.02 & Irri & 24.02 & 24.02 & 4.02 & 24.02 & 1.02 \\
\hline Irri & 24.7 & 98 & .88 & .54 & .42 & & 24.91 & 22.07 & 21.01 & 23.92 & \\
\hline Irrigation9 & 24.37 & .10 & .08 & 3.83 & 1.91 & ion9 & 24.89 & 20.92 & 22.86 & 23.91 & .39 \\
\hline Irrig & 24.86 & 23.26 & 20.85 & 23.59 & 22.08 & Irrig & 24.72 & 22.75 & 24.08 & 23.72 & 22.97 \\
\hline n11 & 4.80 & & .64 & .94 & 1.70 & ion11 & 24.99 & 22.40 & 3.63 & 3.81 & .32 \\
\hline & 24.64 & 38 & 20.51 & 3.77 & 21.45 & Irr & 24.69 & 22.47 & 23.44 & 23.63 & 22 \\
\hline Irri & 2.00 & & 20.94 & 3.17 & 21.70 & Irri & 25.02 & 22.94 & 21.04 & 23.14 & 21 \\
\hline Irri & 24.37 & .66 & 21.21 & 3.39 & 21.59 & Irrig & 25.07 & 22.76 & 21.66 & 23.63 & 22.58 \\
\hline Irri & 24.92 & .82 & 21.68 & 23.23 & 22.28 & Irris & 24.98 & 22.82 & 21.16 & 23.32 & 21 \\
\hline 116 & 25.01 & 2.07 & 20.91 & 3.54 & 22.11 & Irrig & 24.93 & 22.46 & 21.19 & 23.76 & .59 \\
\hline 17 & 25.06 & 21.88 & 21.16 & 23.73 & 21.60 & Irrg & 25.11 & 22.01 & 21.62 & 23.69 & 22 \\
\hline & 24.87 & & 21.58 & 3.85 & 1.62 & Irri & 24.96 & 22.18 & 21.23 & 23.72 & 2.57 \\
\hline Irri & 25.04 & 22.51 & 21.49 & 23.45 & 22.00 & Irris & 25.01 & 22.31 & 21.63 & 23.74 & 22.50 \\
\hline Irrigation20 & 24.69 & 23.04 & 21.39 & 23.91 & 21.66 & Irrig & 24.86 & 22.39 & 22.01 & 23.84 & 22.80 \\
\hline & 25.08 & 24.01 & 23.66 & 24.19 & 23.97 & Irrig & 25.16 & 24.31 & 23.84 & 24.31 & 24.04 \\
\hline n22 & 24.97 & 23.19 & 21.61 & 24.09 & 21.03 & tion22 & 25.34 & 23.61 & 22.46 & 24.19 & 22.53 \\
\hline ion23 & 18.79 & 13.97 & 12.80 & 15.75 & 14.12 & Irrigation 23 & 20.93 & 18.11 & 17.75 & 19.98 & 19.04 \\
\hline
\end{tabular}

$F W$ freshwater, $T W W$ treated wastewater, $\% 100$ full irrigation, $75 D$ and $50 D 75$ and $50 \%$ deficit irrigation, 75PRD and 50PRD 75 and 50\% deficit irrigation with PRD

The variance analyses were carried out using the SAS software (SAS, 2000) and the Duncan multiple comparison test of the Minitab software was used to compare the significant averages (Kesici and Kocabaş, 2007).

\section{Results and discussion}

Tables 6 and 7 show the effects of PRD and D applications on the blossom-end rot in tomato. According to Table 6, blossom-end rot incidences with respect to fruit number varied between $8.57 \%$ and $33.22 \%$. The highest blossom-end rot incidence was obtained in the $50 \% \mathrm{D}$ freshwater applications. The differences between the averages obtained for water resources were statistically not significant, while the differences between the applications were significant. The lowest blossom-end rot incidence was obtained in the $100 \%$ full irrigation applications, while the highest blossom-end rot incidence was obtained in the 50\% D applications. The PRD applications had less effect 
on blossom-end rot than the deficit irrigation applications. In their study, Zegbe et al. (2007) reported that the highest blossom-end rot was obtained in the D (37\%) and PRD (22\%) applications and determined that blossom-end rot was higher in the deficit irrigation application than in the partial root drying application. Obreza et al. (1996) found that blossom-end rot was five times higher in the $30 \%$ deficit irrigation application than in the full irrigation application. In the same vein, Dorji et al. (2005) determined that the highest blossom-end rot incidences were obtained in the deficit irrigation and partial root drying applications. The increased blossom-end rot incidences in deficit irrigation and partial root drying applications are attributable to the water deficit-induced decrease in the calcium content of the fruits (Adams and Ho, 1992).

Table 6. Blossom-end rot incidences with respect to fruit number (\%)

\begin{tabular}{c|c|c|c|c|c|c}
\hline Applications & \% 100 & \% 75 D & \% 50 D & \% 75 PRD & \% 50 PRD & Means \\
\hline FW & $10.85^{\mathbf{c d}}$ & $18.18^{\mathbf{b c d}}$ & $33.22^{\mathbf{a}}$ & $18.42^{\text {bcd }}$ & $21.30^{\text {bc }}$ & 18.71 \\
TWW & $8.57^{\mathbf{d}}$ & $21.59^{\mathbf{b c}}$ & $24.61^{\text {ab }}$ & $19.39^{\text {bcd }}$ & $19.42^{\text {bcd }}$ & 20.39 \\
\hline Means & $9.71 \mathbf{C}$ & $19.88 \mathbf{B}$ & $28.91 \mathbf{A}$ & $18.90 \mathbf{B}$ & $20.36 \mathbf{B}$ & \\
\hline
\end{tabular}

$F W$ freshwater, $T W W$ treated wastewater, $\% 100$ full irrigation, $75 D$ and $50 D 75$ and $50 \%$ deficit irrigation, $75 P R D$ and $50 P R D 75$ and 50\% deficit irrigation with PRD, $\mathrm{p}<0.01$

Table 7. Blossom-end rot incidences with respect to fruit weight (\%)

\begin{tabular}{c|c|c|c|c|c|c}
\hline Applications & \% 100 & \% 75 D & \% 50 D & \% 75 PRD & \% 50 PRD & Means \\
\hline FW & 26.28 & 22.71 & 30.41 & 16.96 & 27.68 & 24.81 \\
TWW & 19.96 & 30.96 & 23.43 & 26.83 & 25.11 & 23.93 \\
\hline Means & 19.79 & 26.83 & 26.92 & 21.90 & 26.39 & \\
\hline
\end{tabular}

$F W$ freshwater, $T W W$ treated wastewater, $\% 100$ full irrigation, $75 D$ and $50 D 75$ and $50 \%$ deficit irrigation, 75PRD and 50PRD 75 and 50\% deficit irrigation with PRD

According to Table 7, the blossom-end rot values with respect to fruit weight varied between 16.96 and $30.96 \%$. The differences between the applications in the ratios of the weight of fruits with blossom-end rot to total fruit weight were not statistically significant.

The higher incidences of blossom-end rot in the deficit irrigation applications is attributable to the activation of the self-defense mechanisms of the plants in response to water stress. Moreover, irregular irrigation and saline water conditions have been reported to be the most common causes of blossom-end rot (Cuartero and FernandezMunoz, 1999; Franco et al., 1999; Zhai et al., 2015). The decrease in the soil moisture in the $\mathrm{D}$ and PRD applications can contribute to the increase in blossom-end rot incidences. According to Table 6, the highest incidence of blossom-end rot was observed in the deficit irrigation applications due to decreased soil moisture (Tables 4 and 5). In their study, Shaykewich et al. (1971) reported that blossom-end rot increased in soils with decreased moisture content. Pill and Mambeth (1980) observed that hardness and blossom-end rot increased in tomatoes under conditions of low $\mathrm{NH}_{4}$ fertilization and soil water potential. It has also been reported that low Ca content in the fruit and deficit irrigation application affected the development of blossom-end rot (Adams and Ho, 1993; Taylor et al., 2004; Ho and White, 2005). Researchers have 
noted that the PRD method is a variation of the deficit irrigation applications and one of its negative effects on the tomato plants is blossom-end rot development (Obreza et al., 1996; Zegbe et al., 2004). In their study in which the effects of PRD and D applications on tomato were investigated, Sun et al. (2013) reported that the PRD applications had a lesser effect on the development of blossom-end rot than the D applications and associated it with the increase in the abscisic acid concentration and the subsequent increase in stomatal conductivity leading to increased calcium uptake and, thus, decreased blossom-end rot development.

There was a statistically significant relationship between blossom-end rot and $\mathrm{Ca}$ contents of the fruit and leaves (Table 8). The first studies about the issue generally reported that blossom-end rot occurred under conditions of Ca deficiency (Hamner et al., 1942; Ward, 1973; Bradfield and Guttridge, 1984; Adams and Ho, 1992). However, blossom-end rot is not only affected by Ca deficiency but also affected by high $\mathrm{Mg}, \mathrm{Na}$, $\mathrm{K}$ and $\mathrm{NH}_{4}$ concentrations, rapid growth, irrigation amount, low Ca content in soil and high or low transpiration (Geraldson, 1955; Kirby and Pilbeam, 1984; De Kreij, 1996; Paiva et al., 1998; Marcelis and Ho, 1999; Franco et al., 1999; Saure, 2001; Taylor and Locascio, 2004). The $\mathrm{K}$ and $\mathrm{N}$ contents of the fruits were also determined to have statistically significant effects on blossom-end rot while in soil, only the effects of $\mathrm{K}+\mathrm{Mg} / \mathrm{Ca}$ and $\mathrm{EC}$ on blossom-end rot were statistically significant. The results indicated that various factors affected blossom-end rot in addition to Ca deficiency.

Table 8. The linear correlation between BER and $\mathrm{Ca}, \mathrm{K}, \mathrm{N}, \mathrm{K} / \mathrm{Ca} \mathrm{K}+\mathrm{Mg} / \mathrm{Ca}$ and $\mathrm{EC}$

\begin{tabular}{c|c|c|c}
\hline & Fruit & Leaf & Soil \\
\hline $\mathbf{C a}$ & $-0.557^{* *}$ & $-0.691^{* *}$ & -0.055 \\
$\mathbf{K}$ & $-0.407^{*}$ & -0.280 & -0.480 \\
$\mathbf{N}$ & $-0.399^{*}$ & -0.300 & -0.160 \\
$\mathbf{K} / \mathbf{C a}$ & -0.264 & $0.380^{*}$ & -0.040 \\
$\mathbf{K}+\mathbf{M g} / \mathbf{C a}$ & -0.290 & $0.465^{* *}$ & $0.396^{*}$ \\
$\mathbf{E C}$ & -0.002 & - & $-0.535^{* *}$ \\
\hline
\end{tabular}

$* * \mathrm{p}<0.01, * \mathrm{p}<0.05$

There was a significant negative relationship between blossom-end rot and the potassium content of the fruits, while the relationship between blossom-end rot and the potassium contents of leaves and soil was not statistically significant. Moreover, there was a significant negative relationship between the nitrogen content of the fruits and BER. There was a significant positive relationship between the $\mathrm{K} / \mathrm{Ca}$ and $\mathrm{K}+\mathrm{Mg} / \mathrm{Ca}$ ratios in leaves and BER. BER had a significant positive relationship with the $\mathrm{K}+\mathrm{Mg} / \mathrm{Ca}$ ratio in soil, while it had a significant negative relationship with EC (Table 8). DeKock et al. (1982) reported that the ratio of K/Ca was a better determinant of blossom-end rot than the Ca content. However, Wada et al. (1996) and Bar-Tal and Pressman (1996) argued that the relationship between $\mathrm{K} / \mathrm{Ca}$ and blossom-end rot did not have a predictive value. Albahou (1999) reported that high salinity contributed to the decrease in the blossom-end rot incidences. However, various researchers are of the opinion that blossom-end rot increases with increasing salinity and $\mathrm{NH}_{4}$ content (Pill and Lambeth, 1980; Nonami et al., 1995; Saure, 2014). 


\section{Conclusion}

In the study in which the effects of the D and PRD methods on blossom-end rot were investigated, the lowest blossom end-rot incidence was observed in the $100 \%$ full irrigation applications. The D application had the highest effect on blossom-end rot development. The PRD method had a lower effect than the deficit irrigation application. The lower incidence of blossom-end rot in the PRD applications compared with the D applications was associated with increased abscisic acid concentration in the xylem, decreased stomatal conductivity and the more effective use of water leading to increased Ca uptake and reduced blossom-end rot development. Therefore, the PRD can be a promising method for water saving under water deficit conditions and reduction of blossom-end rot development in tomatoes.

The results indicated that blossom-end rot was affected by various factors in addition to $\mathrm{Ca}$ deficiency. Furthermore, the results showed that in the production of marketable tomato, the PRD method is more advantageous than the D method under water shortage conditions where full irrigation is limited.

Acknowledgements. A. D. D. thanks the Ataturk University for the financial support of this research project (BAP-2012/414).

\section{REFERENCES}

[1] Adams, P., Ho, L. C. (1992): The susceptibility of modern tomato cultivars to blossomend rot in relation to salinity. - J. Hort. Sci. 67: 827-839.

[2] Adams, P., Ho, L. C. (1993): Effects of environment on the uptake and distribution of calcium in tomato and on the incidence of blossom-end rot. - Plant and Soil 154: 127132.

[3] Albahou, M. (1999): Alternative greenhouse tomato production system. - Ph.D. Thesis, Oregon State University, Oregon.

[4] Al-Lahham, O., El Assi, N. M., Fayyad, M. (2007): Translocation of heavy metals to tomato (Solanum lycopersicom L.) fruit irrigated with treated wastewater. - Scientia Horticulturae 113: 250-254.

[5] Alrajhi, A., Beecham, S., Bolan, N. S., Hassanli, A. (2015): Evaluation of soil chemical properties irrigated with recycled wastewater under partial root-zone drying irrigation for sustainable tomato production. - Agricultural Water Management 161: 127-135.

[6] Bar-Tal, A., Pressman, E. (1996): Root restriction and potassium and calcium solution concentrations affect dry-matter production, cation uptake, and blossom-end rot in greenhouse tomato. - Journal of the American Society for Horticultural Science 121: 649-655.

[7] Bost, S. (2010): Blossom-End Rot. - http://trace.tennessee.edu/utk_agexdise/.

[8] Bradfield, E. G., Guttridge, C. G. (1984): Effects of night-time humidity and nutrient solution concentration on the calcium content of tomato fruit. - Scientia Horticulturae 22: 207-217.

[9] Carrijo, O. A., Oliveira, C. A. S., Olitta, A. F. L., de Fontes, R. P., dos Reis, N. B. B., Della Vecchia, P. T. (1983): A trial comparing drip and furrow irrigation and $\mathrm{N}$ and $\mathrm{K}$ fertilization on tomato (Lycopersicon esculentum Mill.). - Horticultura Brasileira 1: 4144.

[10] Cuartero J, Fernandez-Munoz, R. (1999): Tomato and salinity. - Scientia Horticulturae 78: 83125 . 
[11] De Kreij, C. (1996): Interactive effects of air humidity, calcium and phosphate on blossom-end rot, leaf deformation, production and nutrient contents of tomato. - Journal of Plant Nutrition 19: 361-377.

[12] DeKock, P. C., Inkson, R. H. E., Hall, A. (1982): Blossom-end rot of tomato as influenced by truss size. - Journal of Plant Nutrition 5: 57-62.

[13] Doğan Demir, A. (2016): Farklı Sulama Stratejileri ile Atık Su Uygulamalarının Bingöl Koşullarında Domates Bitkisinin Verim ve Kalitesi ile Toprak Özelliklerine Etkisi. Doktora Tezi, Atatürk Üniversitesi, Fen Bilimleri Enstitüsü, Tarımsal Yapılar ve Sulama Ana Bilim Dal, Erzurum.

[14] Dorji, K., Behboudian, M. H., Zegbe-Dominguez, J. A. (2005): Water relations, growth, yield, and fruit quality of hot pepper under deficit irrigation and partial rootzone drying. Scientia Horticulturae 104: 137-149.

[15] Drechsel, P., Scott, C. A., Raschid-Sally, L., Redwood, M., Bahri, A. (2010): Wastewater Irrigation and Health. - International Water Management Institute and International Development Research Centre, Canada.

[16] Ekici, B. (2002): Sera Domates Yetistiriciliginde Kısmi Kök Kurulugu (Partial Rootzone Drying) Sulama Tekniginin Bitki Büyümesi, Verim ve Meyve Kalitesi Üzerine Etkileri. Y. Lisans Tezi, Çukurova Üniversitesi, Fen Bilimleri Enstitüsü, Adana.

[17] Franco, J. A, Perez-Saura, P. J., Fernandez, J. A., Parra, M., Garcia, A. L. (1999): Effect of two irrigation rates on yield, incidence of blossom-end rot, mineral content and free amino acid levels in tomato cultivated under drip irrigation using saline water. - Journal of Horticultural Science and Biotechnology 74: 430-435.

[18] Geraldson, C. M. (1955): The use of calcium for control of blossom-end rot of tomatoes. - Journal of the American Society for Horticultural Science 68: 197-202.

[19] Gerard, C. J., Hipp, B. W. (1968): Blossom-end rot of 'Chico' and 'Chico Grande' tomatoes. - J. Am. Soc. Hortic. Sci. 93: 521-531.

[20] Greenway, H., Hughes, P. G., Klepper, B. (1969): Effects of water deficit on phosphorus nutrition of tomato plants. - Physiologia Plantarum 22: 199-207.

[21] Hamner, K. C., Lyon, C. B., Hamner, C. L. (1942): Effect of mineral nutrition on the ascorbic-acid content of the tomato. - Botanical Gazette 103: 586-616.

[22] Ho, L. C., White, P. J. (2005): A cellular hypothesis for the induction of blossom-end rot in tomato fruit. - Annals of Botany 95: 571-581.

[23] Ho, L. C., Hand, D. J., Fussell, M. (1999): Improvement of tomato fruit quality by calcium nutrition. - Acta Horticulturae 481: 463-468.

[24] Hussain, I., Raschid, L., Hanjra, M. A., Marikar, F., Van Der Hoek, W. (2002): Wastewater Use in Agriculture: Review of Impacts and Methodological Issues in Valuing Impacts. - Working Paper 37. International Water Management Institute, Colombo, Sri Lanka.

[25] Ikeda H, Osawa, T. (1988): The effects ofNO3/NH4 ratios and temperature of nutrient solution on growth, yield and blossom-end rot incidence in tomato. - Journal of the Japanese Society for Horticultural Science 57: 62-69.

[26] Kesici, T., Kocabaş, Z. (2007): Biyoistatistik. - Ankara Üniversitesi Eczacılık Fakültesi Biyoistatistik Yayın No: 94. Ankara.

[27] Kirkby, E. A., Pilbeam, D. J. (1984): Calcium as a plant nutrient. - Plant, Cell \& Environment 7: 397-405.

[28] Kızıloğlu, F. M., Turan, M., Sahin, U., Kuslu, Y., Dursun, A. (2008): Effects of untreated and treated wastewater irrigation on some chemical properties of cauliflower (Brassica olerecea L. var. botrytis) and red cabbage (Brassica olerecea L. var. rubra) grown on calcareous soil in Turkey. - Agricultural Water Management 95: 716-724.

[29] Koral, P. S. (2006): Topraksız Kültürde Kullanılabilecek En Ucuz Ortamlar Olan Cibre ve Cürufun, Bitki Gelişmesi, Verim ve Ürün Kalitesine Etkileri Yönünden, Perlit ve Sera Toprağ ile Karşılaştırılmaları. - Doktora Tezi, Trakya Üniversitesi, Fen Bilimleri Enstitüsü, Tekirdağ. 
[30] Li, G., Liu, F., Jacobsen, S. E., Jensen, C. R. (2007): Yield and quality of tomato 1rrigated by treated wastewater and prd method. - Conference on Water Productivity in Agriculture and Horticulture 2-4 July, Copenhagen/Foulum, Denmark.

[31] Marcelis, L. F. M., Ho, L. C. (1999): Blossom-end rot in relation to growth rate and calcium content in fruits of sweet pepper (Capsicum annuum L.). - Journal of Experimental Botany 50: 357-363.

[32] Nonami, H., Fukuyama, T., Yamamoto, M., Yang, L., Hashimoto, Y. (1994): Blossomend rot of tomato plants may not be directly caused by calcium deficiency. - Hydroponics and Transplant Production 396: 107-114.

[33] Nukaya, A., Goto, K., Jang, H., Kano, A., Ohkawa, K. (1994): Effect of K/Ca ratio in the nutrient solution on incidence of blossom-end rot and gold specks of tomato fruit grown in rockwool. - Hydroponics and Transplant Production 396: 123-130.

[34] Obreza, T. A., Pitts, D. J., McGovern, R. J., Speen, T. H. (1996): Deficit irrigation of micro-irrigated tomato affects yield, fruit quality, and disease severity. - J. Prod. Agric. 2: 270-275.

[35] Paiva, E. A. S., Martinez, H. E. P., Casali, V. W. D., Padilha, L. (1998): Occurrence of blossom-end rot in tomato as a function of calcium dose in the nutrient solution and air relative humidity. - Journal of Plant Nutrition 21: 2663-2670.

[36] Pill, W. G., Lambeth, V. N. (1980): Effects of soil water regime and nitrogen form on blossom-end rot, yield, water relations, and elemental composition of tomato. - Journal of the American Society for Horticultural Science 105: 730-734.

[37] Reichman, G. G., Grunes, D. L. (1966): Effect of water regime and fertilization on barley growth, water use, and $\mathrm{N}$ and $\mathrm{P}$ uptake. - Agron. J. 58: 513-517.

[38] SAS (2000): Software for Release 8.1. - Statistical Analysis System Institute, Cary, NC, USA.

[39] Saure, M. C. (2001): Blossom-end rot of tomato (Lycopersicon esculentum Mill.) - a calcium-or a stress-related disorder? - Scientia Horticulturae 90: 193-208.

[40] Saure, M. C. (2014): Why calcium deficiency is not the cause of blossom-end rot in tomato and pepper fruit-a reappraisal. - Scientia Horticulturae 174: 151-154.

[41] Selby, A. D. (1896): Investigations of plant diseases in forcing house and garden. - Ohio Agric. Exp. Sta. Bull. 73: 146-221 (from Spurr, 1959).

[42] Shaykewich, C. F., Yamaguchi, M., Campbell, J. D. (1971): Nutrition and blossom-end rot of tomatoes as influenced by soil water regime. - Canadian Journal of Plant Science 51: 505-511.

[43] Spurr, A. (1959): Anatomical aspects of blossom-end rot in the tomato with special reference to calcium nutrition. - Hilgardia 28: 269-295.

[44] Stikic, R., Popovic, S,. Srdic, M., Savic, D., Jovanovic, Z., Prokic, L. J., Zdravkovic, J. (2003): Partial Root Drying (Prd): A new technique for growing plants that saves water and improves the quality of fruit. - Bulg. J. Plant Physiol. 2003(Special Issue): 164-171.

[45] Sun, Y., Feng, H., Liu, F. (2013): Comparative effect of partial root-zone drying and deficit irrigation on incidence of blossom-end rot in tomato under varied calcium rates. Journal of Experimental Botany 64: 2107-2116.

[46] Tan, C. S., Dhanvantari, B. N. (1985): Effect of irrigation and plant population on yield, fruit speck and blossom-end rot of processing tomatoes. - Canadian Journal of Plant Science 65: 1011-1018.

[47] Taylor, M. D., Locascio, S. J. (2004): Blossom-end rot: a calcium deficiency. - Journal of Plant Nutrition 27: 123-139.

[48] Taylor, M. D., Locascio, S. J., Alligood, M. R. (2004): Blossom-end rot incidence of tomato as affected by irrigation quantity, calcium source, and reduced potassium. HortScience 39: 1110-1115.

[49] Thorup, B. (1969): Root development and phosphorus uptake by tomato plants under controlled soil moisture conditions. - Agron. J. 61: 808-811. 
[50] Wada, T., Ikeda, H., Ikeda, M., Furukawa, H. (1996): Effects of foliar application of calcium solutions on the incidence of blossom-end rot of tomato fruit. - Journal of the Japanese Society for Horticultural Science 65: 553-558.

[51] Ward, G. M. (1973): Causes of blossom-end rot of tomatoes based on tissue analysis. Canadian Journal of Plant Science 53: 169-174.

[52] Winsor, G., Adams, P. (1987): Glasshouse Crops. Volume 3. Diagnosis of Mineral Disorders in Plants. - Her Majesty's Stationery Office, London.

[53] Zegbe, A. J., Behboudian, M. H., Clothier, B. E. (2007): Response of tomato to partial rootzone drying and deficit irrigation. - Rev. Fitotec. Mex. 30: 125-131.

[54] Zegbe, J. A., Behboudian, M. H., Clothier, B. E. (2004): Partial rootzone drying is a feasible option for irrigating processing tomatoes. - Agricultural Water Management 68: 195-206.

[55] Zhai, Y., Yang, Q., Hou, M. (2015): The effects of saline water drip irrigation on tomato yield, quality, and blossom-end rot incidence - a 3a case study in the South of China. PLoS One 10: e0142204. 